\title{
DIVERSITY OF PLANT COMMUNITIES IN SECONDARY SUCCESSION OF IMPERATA GRASSLANDS IN SAMBOJA LESTARI, EAST KALIMANTAN, INDONESIA
}

\author{
Ishak Yassir $^{1 *}$ and Arbainsyah ${ }^{2}$
}

Received : 31 August 2012, Accepted : 11 April 2014

\begin{abstract}
Regeneration of Imperata grassland areas is becoming increasingly important, both to create new secondary forest and to recover the original biodiversity. The diversity of plant communities in secondary succession of Imperata grasslands was studied using 45 subplots of 9 linear transects $(10 \mathrm{~m} \times 100 \mathrm{~m}$ ). Data was collected and all stems over $10 \mathrm{~cm}$ dbh were identified, the Importance Values Index (IVI) for all trees were calculated, saplings and seedlings were counted and analysed, and soil samples were taken and analysed. Results showed that after more than 10 years of regeneration, 65 families were encountered consisting of 164 species, which were dominated by Vernonia arborea Buch.-Ham, Vitex pinnata L., Macaranga gigantea (Reichb.f. \& Zoll.) Muell.Arg., Symplocos crassipes C.B. Clarke, Artocarpus odoratissimus Miq., and Bridelia glauca Blume. The effects of regeneration, from Imperata grassland to secondary forest, on soil were the strongest in the A-horizon where an increase in carbon, $\mathrm{N}$ content, and $\mathrm{pH}$ were observed. Our result shows that Imperata grasslands appear to be permanent because of frequent fires and human interferences and so far few efforts have been made to promote sustainable rehabilitation. If protected from fire and other disturbances, such as shifting cultivation, Imperata grassland will grow and develop into secondary forest.
\end{abstract}

Keywords: Imperata grasslands, Importance Values Index, regeneration, secondary succession

\begin{abstract}
ABSTRAK
Regenerasi alami pada lahan alang-alang menjadi semakin penting, baik untuk menciptakan hutan sekunder baru dan memulihkan keanekaragaman hayatinya. Kami mempelajari keanekaragaman komunitas tumbuhan dalam suksesi sekunder di lahan alang-alang menggunakan 45 subplot dari 9 transek linier $(10 \mathrm{mx}$ $100 \mathrm{~m}$ ). Data yang dikumpulkan dan diidentifikasi dari semua jenis yang ditemukan dengan ukuran diameter setinggi dada lebih dari $10 \mathrm{~cm}$, kemudian dihitung dan dianalisis Indek Nilai Penting (INP) baik untuk tingkat pohon, sapling dan anakan, dan sampel tanah yang diambil kemudian dianalisis. Hasil penelitian menunjukkan bahwa selama proses regenerasi setelah lebih dari 10 tahun, 65 famili ditemukan dimana terdiri dari 164 jenis, yang didominasi oleh Vernonia arborea Buch.-Ham, Vitex pinnata L., Macaranga gigantea (Reichb.f. \& Zoll.) Muell.Arg ., Symplocos crassipes CB Clarke, Artocarpus odoratissimus Miq., dan Bridelia glauca Blume. Pengaruh regenerasi dari lahan alang-alang menjadi hutan sekunder terhadap kondisi tanah terkuat di horizon-A, dimana terjadi peningakatan Karbon, Nitrogen dan pH. Hasil penelitian ini menunjukkan bahwa lahan alang-alang tampak permanen karena mengalami kebakaran yang berulang dan campur tangan manusia dan sejauh ini masih sedikit upaya yang telah dilakukan untuk melakukan merehabilitasi yang berkelanjutan. Jika dilindungi dari kebakaran dan gangguan lain seperti peladang berpindah, lahan alangalang akan tumbuh dan berkembang menjadi hutan sekunder.
\end{abstract}

Kata kunci: Lahan alang-alang, Indek Nilai Penting, regenerasi, suksesi

\footnotetext{
${ }^{1}$ Research Institute for Conservation Technology on Natural Resources, East Kalimantan

${ }^{2}$ Eco Integrated Indonesia-Samboja, East Kalimantan, Indonesia

*Corresponding author: ishak.yassir@gmail.com
} 


\section{INTRODUCTION}

East Kalimantan is one of the important tropical forest habitats in the world. Nowadays, large areas of primary forest in East Kalimantan have been changed into secondary forests, like oil palm plantations, timber estate plantations, slash-and-burn agricultures, coal mining as well as Imperata grasslands. In East Kalimantan alone, the rate of deforestation from 2003 to 2006 was around 248,500 ha per year (Ministry of Forestry, 2008).

MacKinnon et al. (1996) mentioned that Imperata grasslands were caused by logging, forest clearing for shifting cultivation, agriculture and grazing, and also by fire. The latter is a result of frequent human interference. When Imperata grasslands are abandoned and not burned regularly, they will undergo a series of vegetation changes, a process called secondary succession. Leps (1987) argued that this early stage of succession influences the later stages of vegetation development, which in turn determine the character of the secondary forest and the recovery of the original biodiversity.

Although the direction of the (early) secondary succession in Imperata grasslands is important, this aspect was hardly investigated in Indonesia. Most studies in Indonesia focused on tropical secondary forests (Brealey et al., 2004; Bischoff et al., 2005). Okimori and Matius (2000) described the secondary forest succeeding traditional slash-and-burn agriculture; in addition Kiyono and Hastaniah (2000) studied the role of slash-and-burn agriculture in transforming dipterocarp forest into Imperata grassland.

Some studies described the effect of fire on tree species composition of lowland dipterocarp forest (Ohtsuka, 1999; Matius et al., 2000; Hashimotio et al., 2000; Slik et al., 2002; Slik and Eichhorn, 2003; Hiratsuka et al., 2006). Recent study by Yassir et al. (2010) described the pathways of the secondary succession in Imperata grasslands in East Kalimantan on the same location where this study was made.
However, Yassir et al., (2010) focused only on understorey species and vegetation that was less than $3.5 \mathrm{~m}$, but vegetation that was higher than $3.5 \mathrm{~m}$ was not sampled.

The paper describes diversity of plant communities upon secondary succession from Imperata grasslands to young secondary forest with more than 10 years of regeneration time. The objectives of this study were (a) to examine how diversity of plant community develops after fire; and (b) to determine whether Imperata grasslands were a final and stable stage of land degradation.

\section{MATERIAL AND METHOD}

\section{A. Study Area}

The study was conducted at Samboja Lestari area (Figure 1), a 1,850 ha reforestation project managed by the Borneo Orangutan Survival Foundation (BOSF). The Köppen system classified the climate of the research area as Af (tropical rainforest). Average yearly precipitation is about $2,250 \mathrm{~mm}$ with a wet period from December to May. The driest month had an average precipitation of $132 \mathrm{~mm}$, and the wettest month of $231 \mathrm{~mm}$. The daily maximum temperature varied from 23 to $31^{\circ} \mathrm{C}$ and the relative humidity was high, around 78 to $94 \%$. The soils were formed on marine sediments of Tertiary age. Top soils were generally slightly coarser than the deeper layers. In the Food and Agriculture Organization (FAO) classification system (FAO, 2001) the soils of Samboja Lestari was classified as acrisols.

\section{B. Data Collection}

All field data were collected in the area of Samboja Lestari (secondary succession). In total there were 45 subplots out of 9 linear transects $(10 \mathrm{~m} \times 100 \mathrm{~m})$. We collected and identified data of all living trees with a Diameter at Breast Height (DBH) more than $10 \mathrm{~cm}$ (trees) (10 $\mathrm{m} \times 20 \mathrm{~m}$ ); DBH 5 and $<10 \mathrm{~cm}$ (saplings) (5 $\mathrm{m} \times 5 \mathrm{~m}) ; \mathrm{DBH}<5 \mathrm{~cm}$ and a height $<1.3 \mathrm{~m}$ (seedlings including shrubs and herbs) $(2 \mathrm{~m}$ x $2 \mathrm{~m}$ ). All plant samples were identified to 


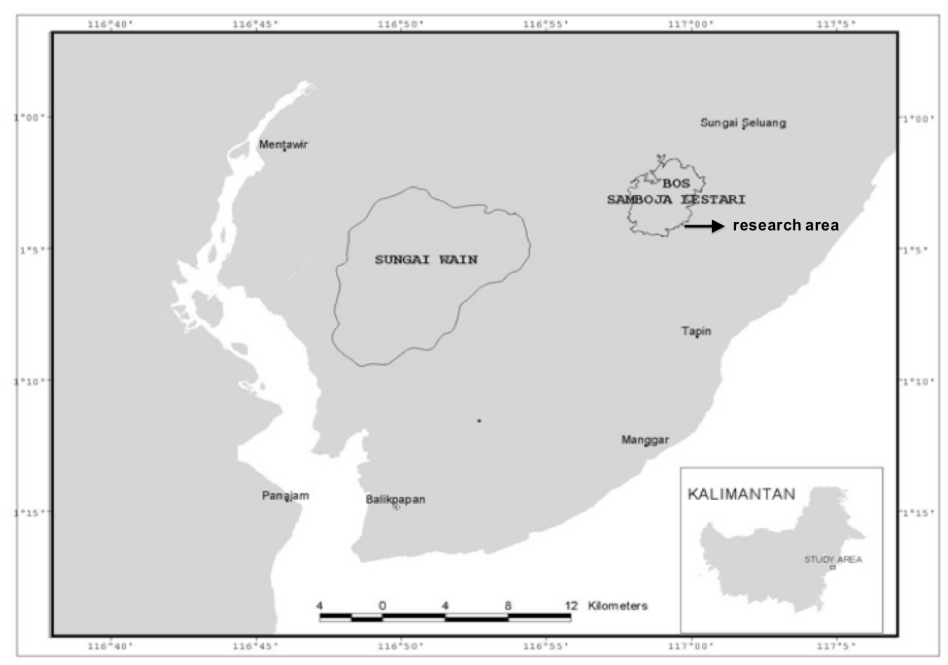

Figure 1. Location of BOS Samboja Lestari, East Kalimantan

the lowest possible taxonomic level. The soil sample of our previous study was collected in similar location and was used for this research (van der Kamp et al., 2009; Yassir et al., 2010). Soil samples were taken from the A-, AB- and B-horizon. As for chemical analyses, samples were taken from the full depth of each horizon. Samples were then taken to the laboratory in labelled plastic bags.

\section{Data Analysis}

All field data were analysed in spreadsheets of Microsoft Excel. The Importance Values Index (IVI) of each tree species were calculated by summing up the relative density, relative dominance and relative frequency. Whereas, the importance values of each species for saplings and seedlings were calculated by summing up the relative density and relative frequency (Mueller-Dombois and Ellenberg, 1974). Methods of soil analysis were listed by van der Kamp et al., (2009) and Yassir et al., (2010). Bulk density of all horizons was measured at Samboja Lestari, using triplicate measurements with $100 \mathrm{~cm}^{3}$ cylinders. Chemical properties were measured at the Soil Science Laboratory of Bogor Agricultural University (Bogor, Indonesia). Chemical measurements included total C determined by Walkley-Black (A-, ABand $\mathrm{B}$-horizon), available $\mathrm{K}$ determined by Bray
I extraction and flame photometer (A- and B-horizon), total $\mathrm{N}$ determined by Kjeldahl/ titrimetric (macro; A-horizons only), available $\mathrm{P}$ determined by Bray I extraction (A- and B-horizon), $\mathrm{pH}$ determined in 1:1 (soil: water) suspension with a $\mathrm{pH}$ meter (A-horizon only).

\section{RESULT AND DISCUSSION}

\section{A. Community Structure}

Based on our 45 subplots with a total area of 0.9 ha in secondary forest, 65 families were encountered consisting of 164 species (Appendix 1). Based on the Important Value Index, the tree species were dominated by Vernonia arborea, Vitex pinnata, Macaranga gigantea, Symplocos crassipes, Artocarpus odoratissimus, and Bridelia glauca (Table 1). The important value index of species of saplings was dominated by Fordia splendidissima, Symplocos crassipes, Macaranga trichocarpa, Malastoma malabathricum, Vitex pinnata and Macaranga beccariana. While, the Important Value Index of species of seedlings including shrubs and herbs were dominated by Nephrolepis bisserrata, Bridelia glauca, Fordia splendidissima, Scleria terrestris, Lygodium circinatum and Psychotria sp.

Furthermore, Kiyono and Hastaniah (1997) reported in their study in East Kalimantan that one hectare of Imperata grassland contained 
Table 1. List of dominance of 10 species based on the Important Value Index (IVI)

\begin{tabular}{|c|c|c|c|c|}
\hline Stages & No. & Species & Family & $\operatorname{IVI}(\%)$ \\
\hline \multirow[t]{10}{*}{ Trees } & 1. & Vernonia arborea & Asteraceae & 62.5 \\
\hline & 2. & Vitex pinnata & Verbenaceae & 40.9 \\
\hline & 3. & Macaranga gigantea & Euphorbiaceae & 27.9 \\
\hline & 4. & Symplocos crassipes & Symplocaceae & 15.3 \\
\hline & 5. & Artocarpus odoratissimus & Moraceae & 11.8 \\
\hline & 6. & Bridelia glauca & Euphorbiaceae & 10.2 \\
\hline & 7. & Artocarpus tamaran & Moraceae & 7.9 \\
\hline & 8. & Melicope glabra & Rutaceae & 6.8 \\
\hline & 9. & Geunsia pentandra & Verbenaceae & 5.6 \\
\hline & 10. & Scbima wallichii & Theaceae & 4.9 \\
\hline \multirow[t]{10}{*}{ Saplings } & 1. & Fordia splendidissima & Leguminosae-Papilionoideae & 29.0 \\
\hline & 2. & Symplocos crassipes & Symplocaceae & 12.0 \\
\hline & 3. & Macaranga trichocarpa & Euphorbiaceae & 11.3 \\
\hline & 4. & Melastoma malabathricum & Melastomataceae & 10.1 \\
\hline & 5. & Vitex pinnata & Verbenaceae & 10.1 \\
\hline & 6. & Macaranga beccariana & Euphorbiaceae & 8.8 \\
\hline & 7. & Bridelia glauca & Euphorbiaceae & 8.2 \\
\hline & 8. & Vernonia arborea & Asteraceae & 7.2 \\
\hline & 9. & Dillenia suffruticosa & Dilleniaceae & 7.0 \\
\hline & 10. & Macaranga gigantea & Euphorbiaceae & 6.9 \\
\hline \multirow{10}{*}{$\begin{array}{c}\text { Seedlings } \\
\text { (including shrubs } \\
\text { and herbs) }\end{array}$} & 1. & Nephrolepis biserrata & Neprolepidaceae & 18.1 \\
\hline & 2. & Bridelia glauca & Euphorbiaceae & 13.0 \\
\hline & 3. & Fordia splendidissima & Leguminosae-Papilionoideae & 11.3 \\
\hline & 4. & Scleria terrestris & Cyperaceae & 11.0 \\
\hline & 5. & Lygodium circinatum & Schizaeaceae & 7.6 \\
\hline & 6. & Psychotria sp. & Rubiaceae & 7.3 \\
\hline & 7. & Melastoma malabathricum & Melastomataceae & 6.1 \\
\hline & 8. & Curculigo racemosa & Amaryllidaceae & 5.6 \\
\hline & 9. & Macaranga beccariana & Euphorbiaceae & 5.5 \\
\hline & 10. & Clidemia birta & Melastomataceae & 5.3 \\
\hline
\end{tabular}

Key: FW= fruit weight, $\mathrm{SS}=$ seed shell, $\mathrm{WS}=$ wet seed, $\mathrm{DS}=$ dry seed

up to 107 plant species, including trees such as Vernonia arborea, Cratoxylum formusum and Vitex pinnata. Hashimotio et al. (2000) reported that after 10-12 years of fallow, the dominant species in regenerated lowland forest in Borneo were Piper aduncum, Ficus sp, Geunsia pentandra, Vernonia arborea, Melastoma malabathricum, Macaranga sp., and Bridelia glauca. Hiratsuka et al. (2006) reported that after the 1998 forest fires in East Kalimantan, the dominant pioneer species were Homalantus populneus, Macaranga gigantea, Macaranga bypoleuca, Mallotus paniculatus,
Melastoma malabathricum, Piper aduncum and Trema orientalis. All these species are described by Kiyono and Hastaniah (1997), Hashimotio et al. (2000) and Hiratsuka et al. (2006) were also identified during our field research.

Compared to our previous study at the same location (Yassir et al., 2010), after three years of regeneration, Imperata cylindrica had the highest average coverage; it became less dominant from the fourth year onward. The average cover of Pteridium aquilinum is initially low but increases after 4 and 9 years of regeneration and also the 
average percentage of shrubs and young trees have increased significantly over time. In the secondary forest other tree species have taken over, and both Imperata and Pteridium have disappeared. Yassir et al., (2010) also reported that after three years of regeneration, Melastoma malabathricum, Eupatorium inulaefolium, and Ficus sp. were dominant species. There was a slight change in the 4-year old growth, where Melastoma malabathricum, Eupatorium inulaefolium, and Ficus sp. became the dominant species. After nine years of regeneration, Melastoma malabathricum, Eupatorium inulaefolium and Vitex pinnata were dominant species following the time of regeneration in Imperata grasslands.
In order to the family dominancy, Euphorbiaceae, Moraceae, Rubiaceae and Lauraceae were the dominant families (Figure 2). Based on our result, the dominant family of Euphorbiaceae is not surprising because Euphorbiaceae family is one of the major families in tropical rain forest in Borneo besides the Dipterocarpaceae family (MacKinnon et al., 1996).

Additionally, distribution pattern of diameter classes upon secondary succession in Imperata grassland showed that the number of species with diameter $10 \mathrm{~cm}-15 \mathrm{~cm}$ were dominant $(51.2 \%)$, followed by diameter $15 \mathrm{~cm}-20 \mathrm{~cm}$ $(28.1 \%)$ and diameter $20 \mathrm{~cm}-25 \mathrm{~cm}(13.0 \%)$

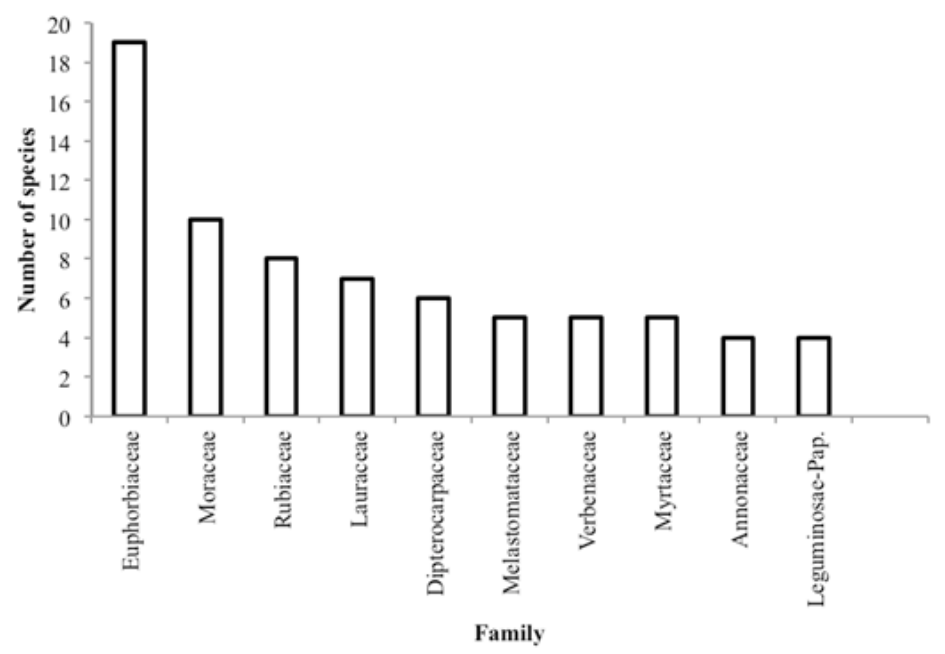

Figure 2. Total observed number of species based on the dominance of 10 families in Samboja Lestari (including seedlings stage)

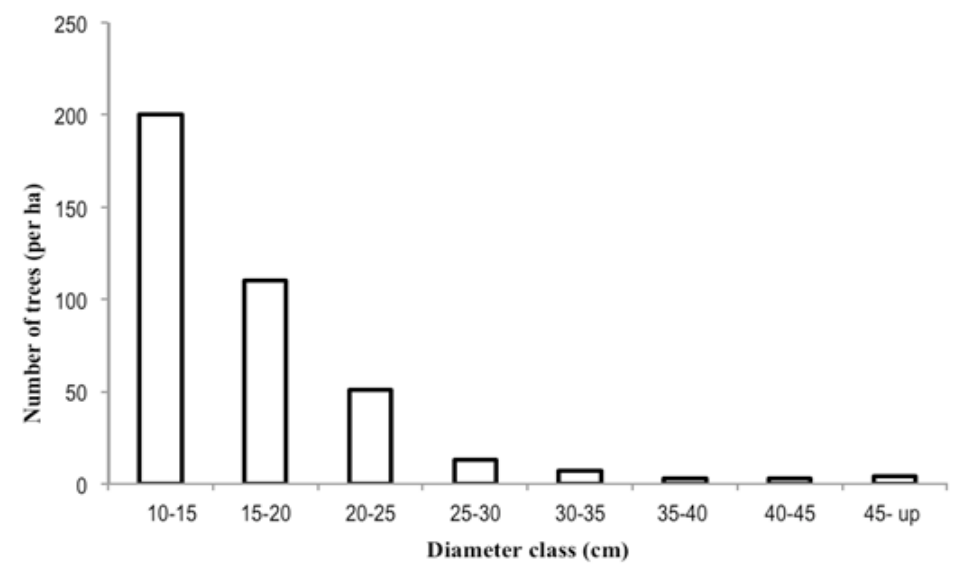

Figure 3. Distribution pattern of diameter classes in secondary succession of Samboja Lestari forest 
Table 2. Soil properties and dominant species in sampled plots at Samboja Lestari

\begin{tabular}{|c|c|c|c|c|c|c|c|c|}
\hline \multirow{2}{*}{$\begin{array}{l}\text { Regeneration } \\
\text { Stage }\end{array}$} & \multicolumn{5}{|c|}{ Means } & \multirow[b]{2}{*}{$\begin{array}{c}\mathrm{P} \\
\left(\mathrm{mg} \mathrm{kg}^{-1}\right)\end{array}$} & \multirow[b]{2}{*}{$\begin{array}{c}\mathrm{K} \\
\left(\mathrm{cmol}^{+} \mathrm{kg}^{-1}\right)\end{array}$} & \multirow[b]{2}{*}{ Dominant species } \\
\hline & $\begin{array}{c}\mathrm{Bd}^{\mathrm{a})} \\
\left(\mathrm{g} \mathrm{cm}^{-3}\right)\end{array}$ & $\mathrm{pH}$ & $\begin{array}{c}\mathrm{C} \\
\left(\mathrm{g} \mathrm{kg}^{-1}\right)\end{array}$ & $\begin{array}{c}\mathrm{N} \\
(\mathrm{g} \mathrm{kg}-1)\end{array}$ & $\mathrm{C} / \mathrm{N}$ & & & \\
\hline \multicolumn{9}{|l|}{3 years $(n=47)$} \\
\hline A-horizon & 1.18 & 5.29 & 14.52 & 1.43 & 10.53 & 4.04 & 0.16 & I. cylindrica \\
\hline AB-horizon & 1.32 & & 8.99 & & & & & E. inulaefolium \\
\hline B-horizon & 1.38 & & 3.75 & & & 3.16 & 0.11 & \\
\hline \multicolumn{9}{|c|}{9 years $(n=126)$} \\
\hline A-horizon & 1.10 & 5.09 & 15.96 & 1.54 & 10.36 & 4.47 & 0.16 & M. malabathricum \\
\hline AB-horizon & 1.34 & & 9.10 & & & & & E. inulaefolium \\
\hline B-horizon & 1.39 & & 3.99 & & & 3.72 & 0.11 & $V$. arborea \\
\hline \multicolumn{9}{|c|}{ Secondary forest ( \pm 15 years; $n=43$ ) } \\
\hline A-horizon & 1.10 & 5.11 & 16.71 & 1.58 & 10.58 & 4.08 & 0.18 & V. arborea \\
\hline AB-horizon & 1.32 & & 8.93 & & & & & $V \cdot$ pinnata \\
\hline B-horizon & 1.41 & & 4.04 & & & 3.60 & 0.10 & S. crassipes \\
\hline
\end{tabular}

*) $\left.\mathrm{Bd}^{\mathrm{a}}\right)=$ bulk density

(Figure 3). The distribution pattern of diameter classes upon secondary succession in Imperata grassland was represented as reversed J shape. The shape of the reversed $\mathrm{J}$ is typical of selfregenerating communities or it describes that the process of regeneration is going well (Felfili, 1997).

\section{B. Soil Properties in Different Phases of Regeneration}

Based on our previous study (Yassir et al., 2010), soil properties in different phases of regeneration indicated that carbon, nitrogen content and $\mathrm{pH}$ in the A-horizon showed a small increase with the regeneration stage from Imperata grassland to young secondary forest (Table 2). When the vegetation was reduced to ashes through burning, as happened in the grassland plots, the $\mathrm{pH}$ increased due to the formation of carbonates (Binkley et al., 1989; Cruz and del Castillo, 2005; Farley et al., 2008). Bulk density generally increases with depth. Bulk density of the A-horizon was fairly high in most recently burned fields. It has decreased during the first phases of succession to secondary forest, possibly due to the appearance of the undergrowth. The carbon content of the A-horizon was the lowest in most recently burned plots. It was increased in the first phases of regeneration from Imperata grassland to secondary forest.

Table 2 also shows that there was no significant increase in $\mathrm{P}$ and $\mathrm{K}$ over time of secondary succession, which may indicate either a limited stock in the soil or leaching from the system. Leaching of $\mathrm{P}$ is unlikely, and therefore a limited supply is probably the best explanation. Yassir et al., (2010) also reported that soil properties had a strong influence on vegetation composition particularly $\mathrm{pH}$, bulk density, sand and clay. Kooch et al., (2007) explained that soil texture and bulk density control the distribution of plant species by affecting moisture availability, ventilation and plant roots distribution. Schoenholtz et al., (2000) mentioned that the relation between bulk density, water and oxygen supply, and soil texture is the most fundamental soil physical property controlling water, nutrient, and oxygen exchange, retention and uptake. More detailed information related to Table 2 is described by 
van der Kamp et al. (2009) and Yassir et al. (2010).

\section{CONCLUSION}

After more than 10 years of regeneration, 65 families were encountered consisting of 164 species, which were dominated by Vernonia arborea, Vitex pinnata, Macaranga gigantea, Symplocos crassipes, Artocarpus odoratissimus, and Bridelia glanca. Our result shows that Imperata grasslands seem to be permanent because of frequent fires and human interferences and so far few efforts have been made to encourage sustainable rehabilitation. If protected from fire and other disturbances such as shifting cultivation, Imperata grassland will develop into secondary forest. Therefore, the assumption that Imperata grasslands are a final stage of land degradation and are very difficult to recover for more valuable land uses is wrong and thus cannot be accepted. The introduction of native shrubs and trees will assist to speed up the process of succession from Imperata grasslands into secondary forest.

\section{ACKNOWLEDGEMENT}

We would like to sincerely thanks to the Gibbon Foundation Indonesia for financial support of this study. Thanks also to Herbarium Wanariset, the laboratory team of Bogor Agricultural University who analysed our samples, and to the staff of StarVision B.V. Indonesia who provided the radar imagery that was used to determine the fire history. Finally we would like to thank Subaidi, Syafaruddin, and other staff of BOS-Samboja Lestari for their support during our fieldwork.

\section{REFERENCES}

Binkley, D., Valentine, D., Wells, C., Valentine, U. (1989). An empirical analysis of the factor contributing to 20-year decrease in soil $\mathrm{pH}$ in an old-field plantation of loblolly pine. Biogeochemistry, 8, 39-54.
Bischoff, W., Newbery, D.M., Lingenfelder, M., Schnaeckel, R., Petol, G.H., Madani, L., Ridsdale, C. E. (2005). Secondary succession and dipterocarp recruitment in Bornean rain forest after logging. Forest Ecology and Management, 218, 174-192.

Brearley, F.Q., Prajadinata, S., Kidd, P.S., Proctor, J., S. (2004). Structure and floristics of an old secondary rain forest in central Kalimantan, Indonesia, and a comparison with adjacent primary fores. Forest Ecology and Management, 195, 385-397.

Cruz, A.B., del Castillo, R. F. (2005). Soil changes during secondary succession in a Tropical Montane cloud forest area. Soil Science Society of America Journal, 69, 906-914.

FAO [Food and Agriculture Organization]. (2001). Lecture notes on major soils of the world. In P. Driessen, J. Deckers, \& F. Nachtergaele (Eds.), Series title: World Soil Resources Reports 94. FAO [Food and Agriculture Organization].

Farley, K. A., Pineiro, G., Palmer, S. M., Jobbagy, E. G., \& Jackson, R. B. (2008). Stream acidification and base cation losses with grassland afforestation. Water Resources Research, $44(7)$.

Felfili, J. M. (1997). Diameter and height distributions in a gallery forest tree community and some of its main species in central Brazil over a sixyear period (1985-1991). Rev. Bras. Bot., 20, 155-162.

Hashimotio, T., Kojima, K., Tange, T., \& Sasaki, S. (2000). Changes in carbon storage on fallow forests in the tropical lowlands of Borneo. Forest Ecology and Management, 126, 331-337.

Hiratsuka, M., Toma, T., Diana, R., Hadriyanto, D., \& Morikawa, D. (2006). Biomass recovery of naturally regenerated vegetation after the 1998 forest fire in East Kalimantan, Indonesia. JARQ, 40(277-282).

Kiyono, Y., \& Hastaniah. (1997). Slash-and-burn agriculture and succeeding vegetation in East Kalimantan (PUSREHUT Spec. Publ Vol 6). PUSREHUT Spec. Publ (Vol. 6). Samarinda: Mulawarman University.

Kiyono, Y., \& Hastaniah. (2000). The role of slash-and-burn agriculture in transforming dipterocarp forest into Imperata grassland. In E. Guhardja, M. Fatawi, M. Sutisna, T. Mori, 
\& S. Ohta (Eds.), Rain Forest Ecosystem of East Kalimantan (El Nino, Drought, Fire and Human Impacts) (Ecological Studies 140) (pp. 199-208). Japan: Springer-Verlag.

Kooch, Y., Jalilvand, H., Bahmanyar, M. A., \& Pormajidian, M. R. (2007). Ecological distribution of indicator species and effective edaphical factor on the Northern Iran lowland forests. Journal of Applied Science, 7, 1475-1483.

Leps, J. (1987). Vegetation dynamics in early old field succession: a quantitative approach. Vegetatio, 72, 95-102.

Mackinnon, K., Hatta, G., Halim, H., \& Mangalik, A. (1996). Ecology of Kalimantan: The Ecology of Indonesia Seri Vol. III.

Matius, P., Toma, T., \& Sutisna, M. (2000). Tree species composition of a burned lowland diptrocarp forest in Bukit Soeharto, East Kalimantan. In E. Guhardja, M. Fatawi, M. Sutisna, T. Mori, \& S. Ohta (Eds.), Rain Forest Ecosystem of East Kalimantan (El Nino, Drought, Fire and Human Impacts) (Ecological Studies 140) (pp. 99-119). Japan: Springer-Verlag.

Ministry of Forestry. (2008). Perbitungan Deforestasi Indonesia. Jakarta: Badan Planologi Kehutanan, Departemen Kehutanan. Indonesia.

Mueller-Dombois, D., \& Ellenberg, H. (1974). Aims and Methods of Vegetation Ecology. New York: Jhon Wiley and Son.

Ohtsuka, T. (1999). Early stages of secondary succession on abandoned cropland in northeast Borneo Island. Ecological Research, 14, $281-$ 290.

Okimori, Y., \& Matius, P. (2000). Tropical secondary forest and its succession following traditional slash-and-burn agriculture in Mencimai, East Kalimantan Ecological Studies 140: pp 185197. In E. Guhardja, M. Fatawi, M. Sutisna, T. Mori, \& S. Ohta (Eds.), Rain Forest Ecosystem of East Kalimantan (El Nino, Drought, Fire and Human Impacts) (Ecological Studies 140) (pp. 185197). Japan: Springer-Verlag.

Schoenholtz, S. H., van Miegroet, H., \& Burger, J. A. (2000). A review of chemical and physical properties as indicators of forest soil quality: challenges and opportunities. Forest Ecology and Management, 138, 335-356.
Slik, J. W. F., \& Eichhorn, K. A. O. (2003). Fire survival of lowland tropical rain forest trees in relation to stem diameter and topographic position. Oecologia, 137, 446-455.

Slik, J. W. F., Verburg, R. W., \& Kebler, P. J. A. (2002). Effects of fire and selective logging on the tree species composition of lowland dipterocarp forest in East Kalimantan, Indonesia. Biodoversity and Conservation, 11, 85-98.

Van der Kamp, J., Yassir, I., \& Buurman, P. (2009). Soil carbon changes upon secondary succession in Imperata grasslands (East Kalimantan, Indonesia). Geoderma, 149, 76-83.

Yassir, I., van der Kamp, J., \& Buurman, P. (2010). 2010. Secondary succession after fire in Imperata grasslands of East Kalimantan, Indonesia. Agriculture, Ecosystems and Environment, 137, 172-182. 
Appendix I. List of all species recorded in young secondary forest in Samboja Lestari

\begin{tabular}{|c|c|c|}
\hline No. & Family & Species \\
\hline 1 & Acanthaceae & Hygropila erecta (Burm.f.) Hochr. \\
\hline 2 & Amaryllidaceae & Curculigo latifolia (Dryand. ex W.T. Aiton) \\
\hline 3 & Amaryllidaceae & Curculigo racemosa Ridl. \\
\hline 4 & Anacardiaceae & Dracontomelon dao (Blanco) Merr. \& Rolfe \\
\hline 5 & Anacardiaceae & Mangifera caesia Jack \\
\hline 6 & Anacardiaceae & Mangipera indica $\mathrm{L}$. \\
\hline 7 & Anacardiaceae & Mangipera pajang Kosterm. \\
\hline 8 & Annonaceae & Artabotrys suaveolens (Blume) Blume \\
\hline 9 & Annonaceae & Mitrephora korthalsiana Miq. \\
\hline 10 & Annonaceae & Popowia pisocarpa (Blume) Endl. \\
\hline 11 & Annonaceae & Uvaria elmeri Merr. \\
\hline 12 & Apocynaceae & Tabernaemontana macrocarpa Korth. ex Blume \\
\hline 13 & Apocynaceae & Willughbeia angustifolia (Miq.) Markgr. \\
\hline 14 & Aquifoliaceae & Ilex cymosa Blume \\
\hline 15 & Arecaceae & Calamus sp. \\
\hline 16 & Aristolochiaceae & Aristolochia jackii Steud. \\
\hline 17 & Asteraceae & Eupatorium inulaefolium Kunth \\
\hline 18 & Asteraceae & Vernonia arborea Buch.-Ham. \\
\hline 19 & Bignoniaceae & Dolicandrone sp. \\
\hline 20 & Blechnaceae & Stenochlaena palustris (Burm.) Bedd. \\
\hline 21 & Celastraceae & Lophopetalum javanicum (Zoll.) Turez,. \\
\hline 22 & Celastraceae & Salacia macrophylla Blume \\
\hline 23 & Compositae & Mikania scandens Willd. \\
\hline 24 & Connaraceae & Roureopsis acutipetala (Miq.) Leenh. \\
\hline 25 & Cornaceae & Alangium javanicum Blume \\
\hline 26 & Cucurbitaceae & Trichosanthes sp. \\
\hline 27 & Cyperaceae & Mapania longiflora C.B. Clarke \\
\hline 28 & Cyperaceae & Scleria terrestris (L,.) Fass. \\
\hline 29 & Datiscaceae & Octomeles sumatrana Miq. \\
\hline 30 & Dilleniaceae & Dillenia suffruticosa (Griff.) Martelli \\
\hline 31 & Dilleniaceae & Tetracera macrophylla Wall. ex Hook.f. \& Thoms. \\
\hline 32 & Dipterocarpaceae & Cotylelobium melanoxylum (Hook.f.) Pierre \\
\hline 33 & Dipterocarpaceae & Hopea dryobalanoides Miq. \\
\hline 34 & Dipterocarpaceae & Parashorea tomentela (Symington) Meijer \\
\hline 35 & Dipterocarpaceae & Shorea johorensis Foxw. \\
\hline 36 & Dipterocarpaceae & Shorea leprosula Miq. \\
\hline 37 & Dipterocarpaceae & Shorea smithiana Sym. \\
\hline 38 & Ebenaceae & Diospyros borneensis Hiern \\
\hline 39 & Ebenaceae & Diospyros confertiflora (Hiern) Bakh. \\
\hline 40 & Ebenaceae & Diospyros sumatrana Miq. \\
\hline 41 & Elaeocarpaceae & Elaeocarpus glaber Blume \\
\hline 42 & Elaeocarpaceae & Elaeocarpus stipularis Blume \\
\hline 43 & Euphorbiaceae & Aporosa nitida Merr. \\
\hline 44 & Euphorbiaceae & Baccaurea motleyana (Muell.Arg.) Muell.Arg. \\
\hline 45 & Euphorbiaceae & Baccaurea sumatrana (Miq.) Muell.Arg. \\
\hline 46 & Euphorbiaceae & Breynea racemosa (Blume) Muell.Arg. \\
\hline 47 & Euphorbiaceae & Bridelia glauca Blume \\
\hline 48 & Euphorbiaceae & Cleistanthus myrianthus (Hassk). Kurz \\
\hline 49 & Euphorbiaceae & Galearia fulva (Tul.) Miq. \\
\hline 50 & Euphorbiaceae & Glocbidion arborescens Blume \\
\hline 51 & Euphorbiaceae & Glochidion sp. \\
\hline 52 & Euphorbiaceae & Homallanthus populneus (Geiseler) Pax \\
\hline 53 & Euphorbiaceae & Macaranga beccariana Merr. \\
\hline 54 & Euphorbiaceae & Macaranga gigantean (Reichb.f. \& Zoll.) Muell.Arg. \\
\hline 55 & Euphorbiaceae & Macaranga motleyana (Muell.Arg.) Muell.Arg. \\
\hline 56 & Euphorbiaceae & Macaranga pruinosa (Miq.) Muell.Arg. \\
\hline 57 & Euphorbiaceae & Macaranga tanarius (L,.) Muell. Arg. \\
\hline 58 & Euphorbiaceae & Macaranga trichocarpa (Reichb.f. \& Zoll.) Muell.Arg. \\
\hline 59 & Euphorbiaceae & Mallotus paniculatus (Lam.) Muell.Arg. \\
\hline 60 & Euphorbiaceae & Omphalea bracteata (Blanco) Merr. \\
\hline 61 & Euphorbiaceae & Trigonostemon laevigatus Muell.Arg. \\
\hline 62 & Fagaceae & Castanopsis $\mathrm{sp}$. \\
\hline 63 & Gleicheniaceae & Dicranopteris linearis (Burm.f.) C.B. Clarke. \\
\hline 64 & Graminae & Imperata cylindrica (L,.) Beauv. \\
\hline
\end{tabular}




\begin{tabular}{|c|c|}
\hline 65 & Graminae \\
\hline 66 & Guttiferae \\
\hline 67 & Guttiferae \\
\hline 68 & Hypericaceae \\
\hline 69 & Hypericaceae \\
\hline 70 & Hypolepidaceae \\
\hline 71 & Lauraceae \\
\hline 72 & Lauraceae \\
\hline 73 & Lauraceae \\
\hline 74 & Lauraceae \\
\hline 75 & Lauraceae \\
\hline 76 & Lauraceae \\
\hline 77 & Lauraceae \\
\hline 78 & Lecythidaceae \\
\hline 79 & Leguminosae-Caes. \\
\hline 80 & Leguminosae-Mim. \\
\hline 81 & Leguminosae-Mim. \\
\hline 82 & Leguminosae-Mim. \\
\hline 83 & Leguminosae-Pap. \\
\hline 84 & Leguminosae-Pap. \\
\hline 85 & Leguminosae-Pap. \\
\hline 86 & Leguminosae-Pap. \\
\hline 87 & Liliaceae \\
\hline 88 & Liliaceae \\
\hline 89 & Loganiaceae \\
\hline 90 & Lycopodiaceae \\
\hline 91 & Magnoliaceae \\
\hline 92 & Malvaceae \\
\hline 93 & Malvaceae \\
\hline 94 & Marantaceae \\
\hline 95 & Marantaceae \\
\hline 96 & Melastomataceae \\
\hline 97 & Melastomataceae \\
\hline 98 & Melastomataceae \\
\hline 99 & Melastomataceae \\
\hline 100 & Melastomataceae \\
\hline 101 & Meliaceae \\
\hline 102 & Meliaceae \\
\hline 103 & Menispermaceae \\
\hline 104 & Moraceae \\
\hline 105 & Moraceae \\
\hline 106 & Moraceae \\
\hline 107 & Moraceae \\
\hline 108 & Moraceae \\
\hline 109 & Moraceae \\
\hline 110 & Moraceae \\
\hline 111 & Moraceae \\
\hline 112 & Moraceae \\
\hline 113 & Moraceae \\
\hline 114 & Myristicaceae \\
\hline 115 & Myrsinaceae \\
\hline 116 & Myrsinaceae \\
\hline 117 & Myrtaceae \\
\hline 118 & Myrtaceae \\
\hline 119 & Myrtaceae \\
\hline 120 & Myrtaceae \\
\hline 12 & Myrtaceae \\
\hline 12 & Neprolepidaceae \\
\hline 12 & Neprolepidaceae \\
\hline $12^{2}$ - r & Pandanaceae \\
\hline 12 & Passifloraceae \\
\hline 12( & Piperaceae \\
\hline 12 & Polygalaceae \\
\hline & Polygalaceae \\
\hline & Rhamnaceae \\
\hline & Rubiaceae \\
\hline & Rubiaceae \\
\hline & Rubiaceae \\
\hline
\end{tabular}

Saccharum sponthaneum L,

Calophyllum nodusum Vasque

Calophyllum sp.

Cratoxylum formosum (Jack) Dyer

Cratoxylum sumatranum (Jack) Blume

Pteridium aquilinum (L,.) Kuhn

Alseodaphne peduncularis (Wall. ex Nees) Meissn.

Cryptocarya crassinervia Miq.

Dehaasia peduncularis Meisn.

Eusideroxylon zwageri Teijsm. \& Binn.

Litsea angulata Blume

Litsea firma (Blume) Hook.f.

Litsea sp.

Barringtonia macrostachya Jack

Baubinia excelsa (Miq.) Prain

Archidendron jiringa (Jack) I.C. Nielsen

Archidendron microcarpum (Benth.) I.C. Nielsen

Paraserianthes falcataria (L,.) I.C. Nielsen

Dalbergia abbrevialata Craib

Fordia splendidissima (Blume ex Miq.) Buijsen

Spatholobus ferrugineus Benth.

Spatholobus hirsutus H. Wiriadinata \& J.W.A. Ridder-Numan

Dracaena elliptica Thunb.

Smilax odoratissima Blume

Fagraea racemosa Jack ex Wall.

Lycopodium cernuum L,

Magnolia tsiampacca (L,.) Dandy

Sida sp.

Urena lobata L,

Phrynium borneensis Blume

Stachyphrynium borneensis (K. Koch) K. Schum.

Clidemia hirta D. Don

Melastoma malabathricum L,

Pternandra azurea (Blume) Burkill

Pternandra sp.

Pternandra rostrata (Cogn.) M.P. Nayar

Chisocheton ceramicus (Miq.) C.DC.

Heynea trijuga (Roxb.) ex Sims

Pericamphyllus glaucus (Lam.) Merr.

Artocarpus anisophyllus Miq.

Artocarpus dadah Miq.

Artocarpus integer (Thunb.) Merr.

Artocarpus nitidus Trec. subsp. borneense

Artocarpus odoratissimus Miq.

Artocarpus tamaran Becc.

Ficus aurata Miq.

Ficus obscura Blume

Ficus sp.

Ficus variegata Blume

Knema latericia Elmer

Embelia javanica DC.

Maesa ramentacea Wall.

Eugenia caudatilimba Merr.

Rhodamnia cinerea Jack

Syzygium lineatum (DC) Merr. \& Perry

Syzygium sp.

Syzygium tawahense (Korth.) Merr. \& Perry

Nephrolepis biserrata (Sw.) Schott.

Nephrolepis sp.

Freycinetia sp.

Passiflora foetida L,.

Piper aduncum L,.

Xanthophyllum affine Korth. ex Miq.

Xanthophyllum rufum A.W. Benn.

Alpitonia excelsa (Fenzl) Reiss ex Endl.

Gardenia tubifera Wall.

Hedyotis congesta Wall. ex G. Don

Nauclea subdita Merr. 


$\begin{array}{ll}133 & \text { Rubiaceae } \\ 134 & \text { Rubiaceae } \\ 135 & \text { Rubiaceae } \\ 136 & \text { Rubiaceae } \\ 137 & \text { Rubiaceae } \\ 138 & \text { Rutaceae } \\ 139 & \text { Sapindaceae } \\ 140 & \text { Sapindaceae } \\ 141 & \text { Sapindaceae } \\ 142 & \text { Sapotaceae } \\ 143 & \text { Sapotaceae } \\ 144 & \text { Schizaeaceae } \\ 145 & \text { Schizaeaceae } \\ 146 & \text { Solanaceae } \\ 147 & \text { Sterculiaceae } \\ 148 & \text { Sterculiaceae } \\ 149 & \text { Symplocaceae } \\ 150 & \text { Theaceae } \\ 151 & \text { Tiliaceae } \\ 152 & \text { Tiliaceae } \\ 153 & \text { Ulmaceae } \\ 154 & \text { Ulmaceae } \\ 155 & \text { Verbenaceae } \\ 156 & \text { Verbenaceae } \\ 157 & \text { Verbenaceae } \\ 158 & \text { Verbenaceae } \\ 159 & \text { Verbenaceae } \\ 160 & \text { Vitaceae } \\ 161 & \text { Vitaceae } \\ 162 & \text { Zingiberaceae } \\ 163 & \text { Zingiberaceae } \\ 164 & \text { Zingiberaceae } \\ & \end{array}$

Pertusadina eurbyncha Ridsdale

Pleiocarpidia polyneura (Miq.) Bremek.

Psychotria sp.

Timonius flavescens (Jack) Baker

Uropbyllum arborescens (Reinw. ex Blume) Korth.

Meticope glabra (Blume) T.G. Hartley

Guioa sp.

Lepisanthes amoena (Hassk.) Leenh.

Nephelium cuspidatum (Blume) var. eriopetalum (Miq.) Leenh.

Madhuca sericea (Miq.) H.J. Lam

Palaquium quercifolium (de Vriese) Burck

Lygodium circinatum (Burm.f.) S.w.

Lygodium microphyllum (Cav.) R.Br.

Solanum jamaicence Mill.

Heritiera elata Ridl.

Sterculia rubiginosa Vent

Symplocos crassipes C.B. Clarke

Schima wallichii (DC.) Korth.

Pentace laxiflora Merr.

Pentace triptera Mast.

Trema tomentosa (Roxb). Hara

Gironniera nervosa Planch.

Clerodendrum adenophysum Hallier $\mathrm{f}$.

Clerodendrum disparifolium Blume

Clerodendrum sp.

Geunsia pentandra Merr.

Vitex pinnata L,

Tetrastigma sp.

Tetrastigma pedunculare (Wall.) Planch.

Alpinia galanga Willd.

Costus speciosus (Koenig) Smith

Etlingera sp. 